\title{
JUURNAL_RU
}

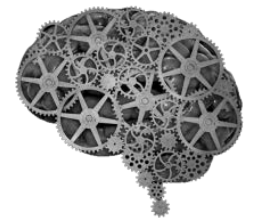

COMPANY GROUP "INTELLEKT"

Колесникова С. Ю. Самарский национальный исследовательский университет имени академика С.П.

Королева

Самара, Россия

doi: 10.18411/lj2016-5-1-07

\section{Анализ технологического процесса получения проводов}

В данной работе проведено исследование технологического процесса изготовления автомобильного провода FLRY-25-C. Автомобильные провода изготовляют в широком ассортименте с медной токопроводящей жилой сечением от 0,13 до 50 кв. мм, и изоляцией из поливинилхлоридных и безгалогенных компаундов различных температурных классов. Для каждого вида и типоразмера провода требуется определенная технология изготовления и соответствующее оборудование. Для повышения производительности процесса получения провода несколько технологических операций объединяют в единый технологический цикл. Создание поточных автоматических линий значительно увеличивает производительность, снижает трудоёмкость и повышает качество продукции. Однако создание таких линий затруднено из-за большой разницы во времени, необходимом для проведения соответствующих операций. Таким образом, необходим комплексный учёт особенностей каждой операции, являющейся частью общего производственного цикла. Принятие решений, касающихся развития, оптимизации или реорганизации производства, обусловлены множеством факторов. 


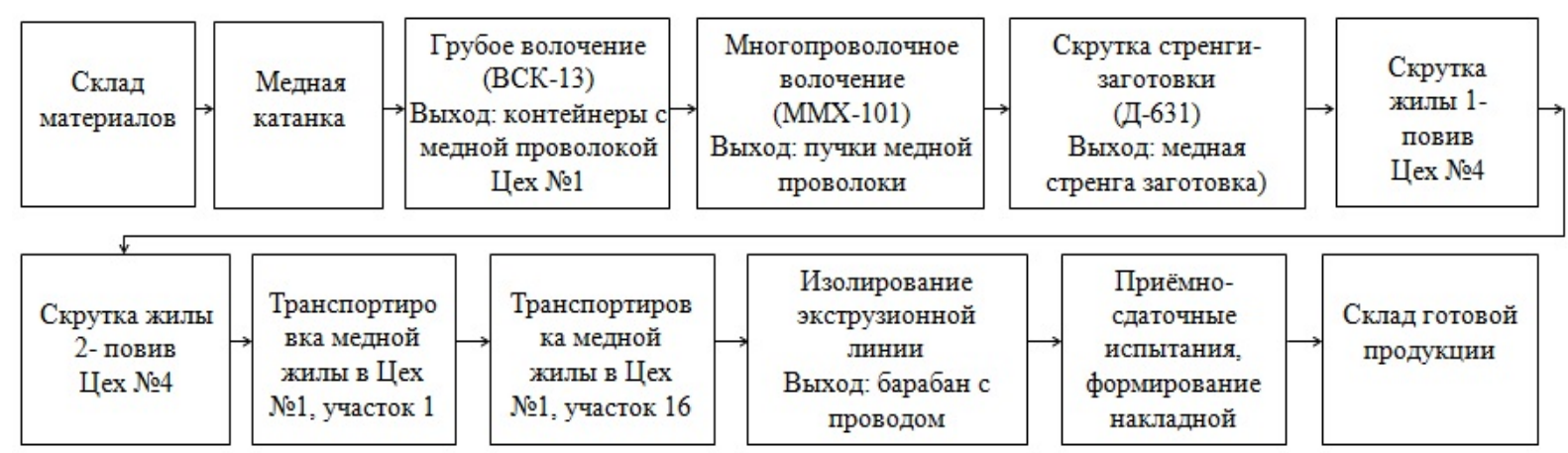

Рисунок 1 - Цепочка изготовления провода FLRY-25-C

Волочение - высокоэффективный технологический метод формообразующей и отделочно-упрочняющей обработки сплошных, полых и многослойных профилей с высокой точностью поперечных размеров и разнообразных сечений.

Для анализа производственной цепочки изготовления 5 км провода FLRY25-С (с общей массой меди 1104 кг) использовались фотографии рабочего места методом непосредственных замеров затраченного времени на каждую операцию. Для запуска скрутки на машине Д-631 стренги-заготовки требуется 3 барабана с пучком по 14 проволок, так как стренга для провода FLRY-25-C состоит из 42 проволок. Таким образом, для получения необходимого количества провода для барабанов с пучком 0,198X42 потребовалось 3 барабана по 96 км/368 кг.

В процессе анализа производственного цикла провода FLRY-25-C выявлены следующие проблемы:

1. Производительность на линии MМХ-101 снижена на 25\% из-за снижения скорости волочения с 27 до 20 м/с.

Причина: повышенная обрывность проволоки.

2. Производительность скрутки снижена из-за неэффективного использования крутильных машин (1-й вместо 2-4-х).

3. Лишний промежуточный пункт назначения медной жилы на участке 1 цеха № 1 перед отправкой на участок 16.

Причина: неоптимально выстроена транспортная цепочка. 
В связи с проведёнными исследованиями предложены следующие мероприятия по решению выявленных проблем с целью оптимизации процесса производства провода FLRY-25-C:

1. Предупреждающая замена изношенных тяговых бандажей на машинах грубого волочения для предотвращения попадания стальных частиц износа в медную проволоку, предназначенную для многопроволочного волочения;

2. Испытание новой улучшенной смазочно-охлаждающей жидкости (волочильной эмульсии) от другого изготовителя, с целью повышения срока службы эмульсии, уменьшения износа волочильного инструмента (алмазных волок), и снижения частоты обрывов проволоки при волочении;

3. Подключение самописца к установке отжига линии № 3 для записи параметров отжига проволоки и определения причин пережога и обрыва медных проволок, часто возникающего в момент остановки волочения;

4. Оптимизировать задание на пучки медной проволоки для скрутки;

5. Улучшить систему планирования организации и логистики на производстве.

\section{Выводы:}

1. Выявлен ряд проблем в производственном цикле изготовления провода FLRY-25-C и предложены мероприятия по оптимизации данного процесса;

2. Внедрение предложенных мероприятий позволяет повысить производительность технологического процесса изготовления провода, сократив длительность производственного цикла на 68 часов. 


\section{Литература:}

1. Перлин И. Л., Ерманок М. З. Теория волочения. М.: Металлургия, 1971. 448 c.

2. Хаймович И. Н., Хаймович А. И. Рационализация организации производства машиностроительного предприятия на основе реинжиниринга //Вестник Самарского государственного аэрокосмического университета им. академика С. П. Королева (национального исследовательского университета), 2006. С. 53-57.

3. Абрамова И. Г., Абрамов Д. А. Повышение эффективности производственных мощностей в свете реализации технологий бережливого и умного производства//Известия Самарского научного центра Российской академии наук, 2013. Т.15. № 6-3. С. 557-562. 